\title{
Refugees and National Security: Two South Asian Case Studies
}

\author{
Partha S Ghosh*
}

\begin{abstract}
Among non-traditional threats to security, the problem of refugees is an important one. Because of political turmoil in several parts of the world, refugee flows are going beyond the capacity of the international system of handle. In South Asia, because of the ongoing conflict between two major nations, India and Pakistan, the issue assumes a serious dimension. We can understand this by studying the following two case studies: the Bangladesh war and the Afghan war. In both cases, the number of refugees was massive and in both cases, America was the principal external actor. But while in the case of Bengali refugees, the host state tried to take advantage of the situation for promoting its foreign policy goals, in the case of Afghan refugees, the host nation tried to use the situation to promote its foreign policy as well as domestic political goals. Although every host state had to face unforeseen consequences, in the long run, it underlines the relevance of the discourse of the refugee-security interface.
\end{abstract}

Keywords: Afghan War, India and Pakistan, Refugees, Security

\section{Introduction}

Apart from Afghanistan, no South Asian state, has a refugee law. In South Asia, therefore, the term is used rather loosely to refer to migrants, unauthorised settlers, and, even internally displaced people such as the displaced Hindus of Kashmir. The focus in this

\footnotetext{
* Institute of Social Sciences, New Delhi, India; parsarg@gmail.com
} 
paper, however, is on the cross-border variety. A rough calculation shows that ever since independence, about 50 million people have crossed the international borders in this region for permanent or semi-permanent settlements. They influence the domestic as well as the foreign policies of both the mother and the host country with inherent security implications. To make sense of this connection, one should focus on some theoretical questions and then try to read the South Asian situation through two case studies, East-Pakistani refugees in India in the wake of the Bangladesh liberation war and Afghan refugees in Pakistan after the Soviet intervention of 1979.

\subsection{Refugee-Security Linkage}

National security is no longer viewed in strictly military terms. Non-military threats have also become equally important. These threats include environmental degradation, poverty, ethnic strife, and pandemics. One such non-military threat concerns the refugees. Civil wars, insurgency, ethnic or religious persecution, and even natural disasters causes the refugees to seek shelter in another country. Refugees affect the host countries in several ways: pressures on resources and civic amenities, threats to internal and external security and even political stability. Quite often they jeopardise the relationship between the mother and the host countries. The first document that defined the refugee, that is, the 1951 Refugee Convention had also talked of this security linkage. After decolonisation, as new states started coming into being gradually, the problem became widespread. It is not well known but the intra-developing country refugee movement is much higher than the one from developing to a developed country. Recent reports suggest that they account for almost 60 percent of the global refugee movement; 35 percent of Asian migrants migrated within the continent (World Migration Report, 2013).

The refugees sometimes indulge in armed campaigns against their mother country, which some scholars have termed as 'refugee warriors'. This, in turn, affects the foreign policy between those two countries. The best example of this is Israel, a nation of diasporas. Moreover, it was the refugee movement that triggered the reunification of Germany. The massive number of East Germans arriving in West Germany as refugees in July-August 
1989 led to the collapse of East Germany and precipitated its absorption by the Federal Republic of Germany. 'It was flight,' wrote Myron Weiner, 'not an invasion, that ultimately destroyed the East German state' (Weiner, 1992-93, p. 91). A decade later, during the Kosovo crisis, the Serbian leader Slobodan Milosevic used the refugee flow as a weapon of war in what was an unbalanced conflict with NATO. It has been often observed that there is a connection between the creation of a new state and the phenomenon of forced migration turning a state and making into a 'refugee-generating process' (Adamson, 2006, p. 172).

International migrations influence three core areas of state power, namely, economic, military and diplomatic, and they all are closely connected to national security. Although the host country could use the talent of skilled migrants, after a while it also faces the problem of unemployment for its own citizens and at the same time, creates the problem of brain drain, for example, the context in African countries. Some of the host countries also take advantage of the skills of the immigrants in the military sector. The U.S., for example, took immense advantage of the refuge-seeking Jews who were subjected to torture by Nazi Germany. It was the Jews like Albert Einstein and Edward Teller that made America the world's first nuclear power. In 2004, the U.S. army recruited as many as 40,000 noncitizens. During the Iraq war, America created a separate division consisting of 3,000 Iraqi expatriates and exiles known as the Free Iraq Forces. India also created its 'Lama Fauj' that was formedout of the Tibetan refugees. In the field of diplomacy, the immigrant communities often work as lobbyists for their country of origin. The lobbying done by the Armenians of Eastern European descent living in America contributed to the enlargement of NATO.

\subsection{The Question of Border}

International relations assume borders to be inviolable, except during wars. But postmodernist scholars argue that it is their potential violation that proves that borders exist. It is argued that national borders are 'political constructs, imagined projections of territorial power... No matter how clearly borders are drawn on official maps, how many customs officials are appointed, or how many watchtowers are built, people will ignore borders whenever it suits 
them. In doing so, they challenge the political status quo of which borders are the ultimate symbol' (Baud \& van Schendel, 1997, pp. 211-12). Even within the nation-state framework, there can be a variety of outlooks held by the armed forces, bureaucrats, politicians, landowners, traders, and captains of industry whose interests may not always converge. It is possible and often happens, that officials stationed in border areas have different opinions about the management of borders than their bosses in the state capitals. It is not uncommon that custom officials are involved in smuggling or security forces are unwilling to risk their lives against powerful separatist groups (Baud \& van Schendel, 1997, pp. 217).

Lately, the works by van Schendel (2002) and James Scott (2009) have sharpened our understanding of the intricate relationship between the mainland and the border regions. They have questioned the limited approach of Area Studies as a sub-discipline of IR which ignores the hinterlands between two states. Van Schendel developed the notion of Zomia (a term derived from Zomi to mean highlander common to several related TibetoBurman languages spoken in the India-Bangladesh-Myanmar borders) to describe the huge mass of mainland South and Southeast Asia that has historically been beyond the authority of the nation-states, Scott by drawing from the same theory argued that while the people of the mainland are the people of the state, the people of the border are those who run away from the state. Yet another perspective for the same could be that colonial powers have created more partitions than anything else, for example partitions in the Indian subcontinent. The by-products of these partitions are the problems of 'minorities', 'new minorities', 'sweat and destitute labor', 'gun-running' and 'drug caravans', 'immigration', and 'alienation', all of which mocks the inviolability of the border. Actually, the border, as Samaddar says, "exteriorises the interior and interiorises the exterior." Paradoxically, while on the one hand illegal migration violates the authority of the state, but on the other, it also upholds the same authority by allowing its exclusive role there (Samaddar, 1999, p. 3; Ghosh, 2016). 


\section{Case Studies of East Pakistan Refugees in India and Afghan refugees in Pakistan from 1979 onwards}

Having discussed above a few broad theoretical points in respect of refugee security connection, two case studies from the South Asian experience is analysed to understand the issue. The first case study deals with the East Pakistan refugees in India in 1971 and the second with Afghan refugees in Pakistan from 1979 onwards. There is one similarity between the two situations: both were massive in scale, and there is one dissimilarity: the security threat in the first case was to the mother state while in the second case it was to the host state which mostly concerned its internal security.

\subsection{Case 1: East Pakistan Refugees in India}

Above a statement by Myron Weiner has been referred in which he said that it was migration and not invasion that destroyed the German state. One may use the same phrase to explain the formation of Bangladesh. The India-Pakistan war of 1971 led to the defeat and dismemberment of Pakistan and resulted in formation of Bangladesh. There was a massive refugee arrival from East Pakistan into bordering Indian states, specifically West Bengal. In a situation like this if the host country is more powerful than the refugee's mother country, and if they are in inimical terms, the security risk for the latter is always huge. The presence of about 10 million East Pakistani refugees on Indian soil not only helped India launch an international campaign against the military rulers of Pakistan but also to gather enough moral justification to use force to make them bend. Prime Minister Indira Gandhi had to create reasonable diplomatic support in the face of general international indifference, if not hostility (Raghavan, 2013), by using the Bengali refugee issue. She emphasised that for a poor country like India it was impossible to cope with the situation. Even if only three rupees was spent per refugee in September 1971 it would have meant US \$ $576,000,000$ for $8,000,000$ camp refugees. By then, the foreign commitment was as little as $\$ 153,670,000$ of which only $\$ 20,470,000$ only had actually arrived and the situation gradually worsened (Raghavan, 2013, pp. 206-7; Bass 2013, p. 249). During her visit to the United States, Indira Gandhi underlined that at the time when India had attained food security and things had just started to look 
good, the huge human tragedy at the India-East Pakistan border that was thrust upon her country, strained the national resources to such an extent that it would threaten the country's 'hard-earned stability'. In the state dinner hosted by President Richard Nixon on 4 November 1971 she did not make any effort to charm her host and others present there but toasted in most matter-of-factly way:

Can you imagine the entire population of Michigan State suddenly converging onto New York State? Imagine the strain on space, on the administration, on services such as health and communications, on resources such as food and money, and this not in condition of affluence, but in a country already battling with problems of poverty and population.... Our administration, already strained to meet the rising demands of our vast population, is stretched to the limit in looking after nine million refugees, all citizens of another country. Food stocks built against drought are being used up. Limited resources scraped together for sorely needed development works are being depleted (Bass, 2013, p. 251).

Then, appealing to American conscience she asked: 'Has not your own society been built of people who have fled from social and economic injustices?' (Bass 2013, p. 251).

Although Indira Gandhi's U.S. sojourn did not impress the NixonKissinger duo to change their pro-Pakistan stance for they were more concerned about maintaining good relations with Pakistan so that they could use its good offices to establish contacts with Mao's China but it certainly earned public and opposition-Democratic sympathy, particularly that of the indomitable Democratic leader, Senator Edward Kennedy (Dem. MA). His report to the Senate Committee on the Judiciary was a harsh indictment of the U.S. government posture. It said, 'It is time ... for Americans to understand what has produced this massive human tragedy and to recognise the bankrupt response of our government. It is time for Americans to understand that we must rescue the ideals of our foreign policy from cold calculations that have not only shaken and demoralised South Asia but many other parts of the world as well' 48 
(Kennedy 1971, p. v). The report was particularly critical of the U.S. policy of continued military assistance to the dictatorial regime of General Yahya Khan: "Nothing has come to symbolize more the intransigency of American policy of supporting Islamabad, than the shipments of military supplies. And nothing has come to symbolise more the bankruptcy of this policy-carried out in the name of "leverage" - than the simple fact that the repression of East Bengal and the flow of refugees into India continues. And war is closer today than ever before" (Kennedy 1971, p. 59).

Gandhi knew the importance of public opinion in any democracy and more so in the United States. She, therefore, made it a point to spend time in New York before reaching Washington to build her popular support. Huge public opinion support was built up against the Pakistani atrocities and in favour of the Bengali uprising. It was the time when America was preparing for the opening up of China in which the presidential adviser Henry Kissinger needed the logistical support of Pakistan. NixonKissinger duo, therefore, was in no mood to listen to the voice of reason and human rights (details in Bass, 2013). India was not unaware of these realities yet it was keeping its powder dry for the inevitable showdown with Pakistan. To achieve the goal, two things were necessary, one, enlisting the support of the Soviets in case of the eventuality of an India-Pakistan war which might see the United States supporting Pakistan, and two, making the military use of the refugees to whatever extent possible. To achieve the latter, India decided to give military training to some sections of the Bengali refugees. They were first trained as Mukti Fauj and later as Mukti Bahini whose cooperation during the India-Pakistan war proved vital for inflicting substantial damage to static installations and infrastructure in East-Pakistan such as bridges, roads, railroads, water transportation networks, power stations, communication systems, and ships in the Chittagong port. The Mukti Bahini had the full logistical support from the Indian armed forces, particularly the Border Security Force (BSF) (Raghavan, 2003, pp. 310-13; Bass 2013, pp.178-88). Indeed the Indian troops were on the East-Pakistan soil before Yahya Khan had declared war against India on 3 December 1971. In fact, India had decided to declare war against Pakistan the next day (Bass, 2013, p. 271). 
There was a non-military security compulsion also. India believed that behind the flow of refugees was the calculated design on the part of Pakistan to push millions of East-Pakistani Hindus to India so as to neutralise the numerical advantage of East-Pakistan vis-avis West-Pakistan which all the U.S. diplomats stationed in Pakistan had been constantly reporting (Weiner 92-93, p. 123, Bass, 2013). India knew that more and more Hindu refugees were arriving which by the end of 1971 had reached the ratio of 82:18, a fact that CIA and U.S. Consulate at Dhaka had reported to the Nixon government (Raghavan, 2013, pp. 76, 120, 206; Bass, 2013, pp. 154, 236-37). Knowing its domestic political fallout, the Indian decision-makers assiduously downplayed this fact (Bass, 2013, pp. 121-22). If they didn't do it, it would have caused serious communal tensions, and might have even led to Hindu-Muslim riots. To avert such a situation, Indira Gandhi took the Jana Sangh leader Atal Bihari Vajpayee into confidence. She requested him not to politicise the issue for otherwise it would give Pakistan a handle to portray the problem of refugees as a Hindu-Muslim one thereby defeating the Indian policy aimed at the probable return of the refugees to East-Pakistan (Raghavan, 2013, p. 76).

There was yet another dimension that had much to do with the future planning aimed at promoting India's politico-strategic interests vis-a-vis Pakistan. Among the refugees was the Awami League leadership which had set up a Bangladesh Government in Exile in Calcutta. The Government of India and the Bangladesh Government in Exile coordinated their political strategies to mutual benefit. India had four principal objectives in mind. First, to see to it that Pakistan lost its eastern province; second, to see that the refugees returned to Bangladesh; third, the communists, particularly the pro-Chinese section, did not gain in political strength through the liberation movement; and fourth, the new nation accepted India's pre-eminence in the region. Except for the last point, which was to be endorsed more by implication than by explicit declaration, all the rest were clearly endorsed by the Awami League. The first objective clearly does not require any documentation. Regarding the second and third there were clear evidences that the Bangladesh Government in Exile had endorsed them. The fact that in Bangladesh politics, India still has many detractors, while Awami League stands out as its support, it has its 50 
history in the events of these fateful days of Bangladesh crisis (for details, see Ghosh, 1989, pp. 57-64).

The third point which had the reference to China needs some elaboration as it had an important internal security angle because of its connection with the Naxalite movement in West Bengal. In this, the China factor loomed largely. In the wake of the Cultural Revolution (1966-76), the Chinese not only had aided the separatists in some of India's North-Eastern states, their Chairman Mao Zedong had also met a group of Naxalites in December 1967. Mao had expressed his complete agreement with the ideological stance of the Naxalites and had even promised them a trade-off if they succeeded in their mission, namely, the acceptance of McMahon Line as China's border and requisite guerrilla training for the Naxal cadres in Champing Military School on the outskirts of Beijing (Raghavan, 2013, p. 193). But in spite of such menacing possibility, Indira Gandhi tried to keep China informed about India's concern about the refugee problem and sought China's cooperation in resolving the issue. In a letter to Zhou Enlai dated 18 July 1971, she wrote that "I am encouraged in the belief that the time may be propitious to seek an exchange of views with you on a matter of current importance" to which Zhou never responded (Raghavan, 2013, p. 199).

One of the important foreign policy expressions for modern democracies is the use of human rights violations in other countries. Either as humanitarian intervention or as Right to Protect (R2P) there is an increasing tendency on behalf of Western powers to intervene in ethnic or sectarian wars in the developing world or in the erstwhile Soviet provinces. NATO's intervention in the Bosnian crisis was one such example. It may be suggested that in this connection, India's Bangladesh war behind which was the presence of millions of East-Pakistani refugees in India, was probably the first such humanitarian intervention in this case by a developing country as a foreign policy tool. According to the Indian scholar Pratap Bhanu Mehta:

India's 1971 armed intervention in East Pakistanundertaken for a mixture of reasons - is widely and fairly regarded as one of the world's most successful cases of humanitarian intervention against genocide. 
Indeed, India in effect applied what we would now call the 'responsibility to protect' (R2P) principle, and applied it well (quoted by Bass 2013, p. 334).

\subsection{Case 2: Afghan Refugees in Pakistan}

Pakistan's experience vis-a-vis Afghan refugees in the post-Soviet invasion phase also highlights the connection between refugees and security. About 3.5 million Afghan Pashtuns took shelter in Pakistan, mostly in the northwest Frontier Province (now Khyber Pakhtunkhwa). Their presence on Pakistan's soil was a boon for the dictatorial regime of Zia-ulHaq which had already ensured American support for its continuation in power through massive military and economic assistance as a frontline state in America's war in Afghanistan. The refugees were the potential mujahedeen (freedom fighters) who the Americans required. With their presence, Islamism came handy to Zia for furthering his Islamic cause and for perpetuating his political dominance. He effectively used both Islam and the traditional code of Pushtunwali to justify his decision of giving refuge to millions of Afghan refugees. In Islamic tradition, the migration of Prophet Mohammad and his companions from Mecca to Medina in $622 \mathrm{CE}$ to avoid persecution known as hijrat (migration) has huge respect and as such the Afghan refugee influx served as a boon to Zia's pro-Islamic strategy. Since most of the Afghan refugees were Pashtuns, the Pashtun traditions of melmasia (hospitality) and panah (refuge) came into play to suit the situation well (Ghufran, 2011, p. 948).

But gradually these refugees became a liability for the Zia regime. A pernicious nexus developed between the multi-million dollar illegal trade in narcotics and arms on the one hand and the massive corruption in the politico-military-bureaucratic establishment on the other. It not only affected Pakistan's political development, but dragged Pakistan into the vortex of factional ethnic conflicts with Afghanistan which it found difficult to extricate itself from. As the Afghan situation became complicated, Pakistan's federal problems in North West Frontier Province multiplied for it was the home of the same ethnic groups to which the major warring factions engaged in the Afghan civil war belonged. Still, the Taliban regime that ruled Afghanistan from 1996 to 2001 following an intense civil 
war was pro-Pakistan, which the latter had raised from amongst the refugees. The Pakistan army had trained them for the job to Pakistan's advantage. It had been the strategic requirement of Pakistan to have a friendly regime in Afghanistan through which it could fulfill its need for strategic depth given its rivalry with India. These developments cast their shadow on India-Pakistan-Iran relations causing complications for South Asian regional security.

Following 9/11 which resulted in the collapse of the Taliban regime once again, there was an exodus of Afghan refugees. The U.S. led bombing campaign that started in October 2001 not only led thousands of Pashtuns to take refuge in Pakistan in a fresh wave but also affected the process of UNHCR-sponsored repatriation drive. For several ethnic and political reasons, the Pashtun, Tajik, Uzbek and Hazara refugees sheltered in Pakistani and Irani camps refused to go back. Throughout the first decade of this century, it was a difficult task for both the Pakistan government and the UNHCR to manage the Afghan refugee problem as all policies seemed to fail to repatriate them. Many of them went back to Afghanistan only to come back again as the situation there was not conducive for a peaceful existence and also to take advantage of the financial incentive provided by the UNHCR for their return (Ghufran, 2011 pp. 948-53).

The Taliban militancy has now spilled over into Pakistan in the form of several indigenous militant outfits the most notable being the Tehrik-i-Taliban Pakistan (TTP). It has posed a serious threat to Pakistan's political stability. In the situation of U.S. withdrawal from Afghanistan, even if it is partial and staggering, the fear of India is that Afghan militancy coupled with the issue of constant Afghan migrations to Pakistan would not leave India unaffected. The challenge for India is how to handle the paradox called Af-Pak. The paradox is this: the United States and its allies depend (pending total U.S. withdrawal, this dependence would continue) on Pakistan for access to the 'war theatre' and to keep the supply lines open. They must thus accept the political conditions set by Islamabad to keep the arrangement. Yet, the whole purpose of the war was to deny the safe haven provided to Al Qaeda by the Taliban regime and eradicate the forces of terrorism and fundamentalism from Afghanistan. If the latter continue to be 
supported and financed from Islamabad (though they also get help from elsewhere), the US-Pakistan arrangement itself becomes selfdefeating. Its short-term logistical advantage is more than offset by a long-term bolstering of the very enemy Washington is fighting. In fact, there is a misalignment between Pakistan's interests in Afghanistan and those of the United States (Heine \& Ghosh, 2011). Still, what Ayesha Jalal writes seems to be the hard reality. She argues that it is not realistic for America to break off ties with Pakistan and lean more heavily on Indian monetary and military help to rebuild Afghanistan: "Most security experts on the region grudgingly concede that American success in Afghanistan depends on the Pakistani army. Paradoxically, this army is the main obstacle as well as the key to peace in Afghanistan (Jalal 2014, p. 5, emphasis added)."

\section{Conclusion}

Among non-traditional threats to security, the problem of refugees is increasingly becoming one. Because of political turmoil in several parts of the world, refugee flows are going beyond the capacity of the international system of handle. As the phenomenon is closely linked to religious and ethnic militancy, human sentiments are coming in the way of a rational and humanitarian solution. In South Asia because of virtually unenforceable borders and the unfinished tasks of nation-building, refugee movements are common. Once in the host country, they keep lobbying the host government to take up positions hostile to the country of their origin which complicates bilateral relations. It may also tempt the host nation to settle its scores with the mother countries if they are in hostile terms. Sometimes the refugees, if they are in sizable numbers and belong to one or more of the local ethnic groups, lead to internal political complications in the host state, which has internal security implications. Since all countries have international connections, these complications do not remain confined to the bilateral relations and assume international dimensions. In both the case studies, it is noticed how the role of the United States has been critical. There is no respite from these complexities impinging upon regional security however much we like to usher in. 


\section{References}

Adamson, F. B. (2006). Crossing Borders: International Migration and National Security. International Security, 31(1), 165-99.

Bass, G. J. (2013). The Blood Telegram: Nixon, Kissinger and a forgotten genocide. New York: Alfred A. Knopf.

Baud, M., \& Schendel, W. (1997). Toward a comparative history of Borderlands. Journal of World History, 8(2), pp. 211-42.

Ghosh, P. S. (1989). Cooperation and conflict in South Asia: New Delhi: Manohar. Sage.

. (2016). Migrants, refugees and the stateless in South Asia. New Delhi:

Ghufran, N. (2011). The role of UNHCR and Afghan refugees in Pakistan. Strategic Analysis (New Delhi), 35(6), pp. 945-54.

Heine, J., \& Ghosh, P. S. (2011). The Elephant in the war: India and the Afghan-Pakistan link. Canadian Foreign Policy Journal (Ottawa), 17(1), pp. 50-61.

International Labour Organisation. (2013). World Migration Report: A right based approach. Geneva: ILO Publications.

Jalal, A. (2014). The struggle for Pakistan: A Muslim homeland and global politics. Cambridge: Mass.: The Belknap Press of Harvard University Press.

Kennedy, E. M. (1971). Crisis in South Asia: A report by Senator Edward M. Kennedy to the subcommittee to investigate problems connected with refugees and escapees of the committee on the Judiciary, United States Senate. Washington DC: Government Printing Office.

Raghavan, S. (2013). 1971: A global history of the creation of Bangladesh. Ranikhet: Permanent Black.

Samaddar, R. (1999). Borders, anxieties about borders and all that. Paper presented at the International Conference on Cooperation in South Asia: Resolution of Inter-State Conflicts, Jawaharlal Nehru University, New Delhi, 29-30 March.

Scott, J. C. (2009). The art of not being governed: An anarchist history of upland Southeast Asia. New Haven, CT: Yale University Press.

vanSchendel, W. (2002). Geographies of knowing, geographies of ignorance: jumping scale in Southeast Asia. Environment and Planning D: Society and Space, 20, 647-68.

Weiner, M. (1992-93). Security, stability, and international migration. International Security (Cambridge, MA), 17(3), Winter. 